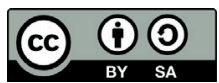

\title{
BUILDING PROFESSIONAL COMPETENCES OF SOCIAL WORKERS THROUGH DISTANCE LEARNING IN THE CONTEXT OF THE COVID-19 PANDEMIC
}

\author{
Tetiana Liakh ${ }^{1}$, Tetiana Spirina ${ }^{2}$, Maryna Lekholetova $^{3}, \&$ Olha Shved ${ }^{4}$ \\ Borys Grinchenko Kyiv University, Ukraine \\ ${ }^{1}$ t.liakh@kubg.edu.ua, ORCID 0000-0002-8807-0497 \\ 2 t.spirina@kubg.edu.ua, ORCID 0000-0003-0287-7343 \\ 3 m.lekholetova@kubg.edu.ua, ORCID 0000-0003-4055-991X \\ ${ }^{4}$ o.shved@kubg.edu.ua, ORCID 0000-0003-4251-3894
}

\begin{abstract}
The article is devoted to the issue of distance learning. It discusses the relevance and grounds of using distance learning tools in the education process of higher education institutions in the context of the COVID-19 pandemic and describes the organization of distance learning at the Borys Grinchenko Kyiv University during the COVID-19 pandemic. The authors present the professional competences of social work specialists and academic disciplines that form these competences on the example of the educational program "Social Advocacy" of the first level of higher education (Bachelor) as well as the basic ICTs in the process of distance learning used by teachers of the Department of Social Pedagogy and Social Work in the context of the COVID-19 pandemic. The authors introduce the expected results of implementation and realization of distance learning in the education process of higher educational institutions in the conditions of the COVID-19 pandemic.
\end{abstract}

Keywords: COVID-19; distance learning; adaptation process; professional competences; social work specialist; professional training; information and communication technologie.

\section{INTRODUCTION}

The relevance of the study is due to the global pandemic COVID-19 and the lasting of adaptive quarantine in Ukraine from March 12, 2020 (On prevention of the spread of COVID-19 acute respiratory disease caused by the SARS-CoV-2 coronavirus in Ukraine, 2020). Due to quarantine restrictions, not only the business sector, government and public sectors needed adjustments, but also the education sector, so it was forced to make numerous changes in its functioning in order to continue to 
provide educational services. In particular, there are risks in the quality training of students of higher education institutions (hereinafter HEIs) in Ukraine.

Given the new challenges in the education system, the priority of its renewal in the HEI has become to improve existing and to introduce new tools of distance learning, which would ensure the further formation of professional competences of students of all specialties, accessibility, and effectiveness of higher education. The Borys Grinchenko Kyiv University was no exception and became ready for a new challenge of online learning, therefore appropriate organizational and methodological conditions were developed in this HEI.

\section{Literature review}

During the COVID-19 pandemic, researchers are increasingly focused on studying various aspects of the development and implementation of distance learning tools. In particular, the creation of effective blended learning and the introduction of adaptive learning in higher education institutions have been studied by N. Morze, E. Smyrnova-Trybulska, T. Terletska, L. Varchenko-Trotsenko, V. Vember (Morze \& Vember et al., 2019; Morze \& Varchenko-Trotsenko et al., 2021).

The challenges and needs of the educational institutions in the implementation of distance education and digital tools in the conditions of quarantine caused by the COVID-19 pandemic have been studied in different countries - Ukraine (Ivaniuk \& Ovcharuk, 2020), Spain (García-Peñalvo et al., 2021), Peru (Canales Inga et al., 2021). Researchers emphasize the need to find new ways of teaching due to the impact of COVID-19 on the education system. In particular, to use new learning scenario in order to adapt the teaching processes without the students losing the acquisition of competences (Domínguez-Lloria et al., 2021).

University, as a social institution as defined in the European Higher Education Area, must be a benchmark in the preparation for beginning employment and education for the exercise of active citizenship. Therefore the education requires bringing together specific and generic competences (Regueiro et al., 2021).

The current state of digital learning and prospects for the development of digital competences in Ukrainian universities are presented in the research of such scientists as O. Buinytska, O. Kobylin, O. Kuzminska, M. Mazorchuk. They emphasize that to achieve the goals of higher education and support educational activities, modern universities should create a digital learning environment (Morze \& Buinytska, 2019; Kuzminska \& Mazorchuk, 2020).

Studying the challenges of vocational education in the context of the digital economy, researchers T. Noskova, T. Pavlova, O. Yakovleva stressed that changes in professional activities should be dynamically reflected in the professional training programs. They explored various categories of educational aspects of the distance learning environment: learning the content of educational material; communication for educational purposes through the network; self-management and self-realization in educational activities (Noskova \& Pavlova et al., 2019).

R. Pavliuk, T. Liakh, O. Bezpalko, N. Klishevych studied the issues of training social specialists by means of research methods with the use of research training and ITC tools. In particular, they identified the features of training future professionals in 
the social sphere based on research; analyzed educational programs in the specialty "Social Work" (Pavliuk \& Liakh et al., 2017), as well as approaches to developing a standard of the competences of using ICT in the system of science-based training of future social workers in Ukraine (Pavliuk \& Liakh, 2019).

\section{ORGANIZATION OF DISTANCE LEARNING AT BORYS GRINCHENKO KYIV UNIVERSITY IN THE CONTEXT OF THE COVID-19 PANDEMIC}

The procedure for organizing distance learning at Borys Grinchenko University of Kyiv is specified in the Regulations on the organization of the education process (2017) (Regulations on the organization of..., 2017). The Regulations also provide the right and procedure for forming an individual educational trajectory for students of Borys Grinchenko Kyiv University, which is provided by the following regulations: Development strategy (program) of Borys Grinchenko Kyiv University for 2018-2022, (Development strategy (program)..., 2018); Regulations on the procedure for exercising the academic mobility right by the participants of the education process of Borys Grinchenko Kyiv University (Regulations on the procedure for exercising..., 2018).

Ensuring full-time and part-time education at Borys Grinchenko Kyiv University is implemented using distance learning technologies regulated by the Concept of digitalization for 2020-2022 adopted at the University (The Concept of digitalization..., 2020), which states the construction of the Digital Campus. According to that, all participants in the education process have access 24/7/365 to quality information, which will contribute to the higher quality of education for students and will increase the competitiveness of the University (Buinytska \& Varchenko-Trotsenko et al., 2020). The priority areas of digitalization for the University are following: development of high-quality open information and educational environment of the University; development of an open educational platform; improving the E-learning system; introduction of webinars, online seminars, video, and online lectures, video conferences; development of digital competence of participants of the education process; gradual transition to electronic document management; introduction of visualized business intelligence systems for quick decision making; introduction of personalized Internet access via wireless managed networks; implementation of "remote desktops" of employees through cloud technologies; creation of a digital campus with digital offices for students and employees; virtualization; cybersecurity (The Concept of digitalization..., 2020, p. 3; Kuzminska \& Mazorchuk, 2020).

To implement distance (blended) learning, teachers and students at Borys Grinchenko Kyiv University work with the LMS Moodle (Modular Object-Oriented Dynamic Learning Environment), since September 2020, reformatted into the Digital Campus (Figure 1). 


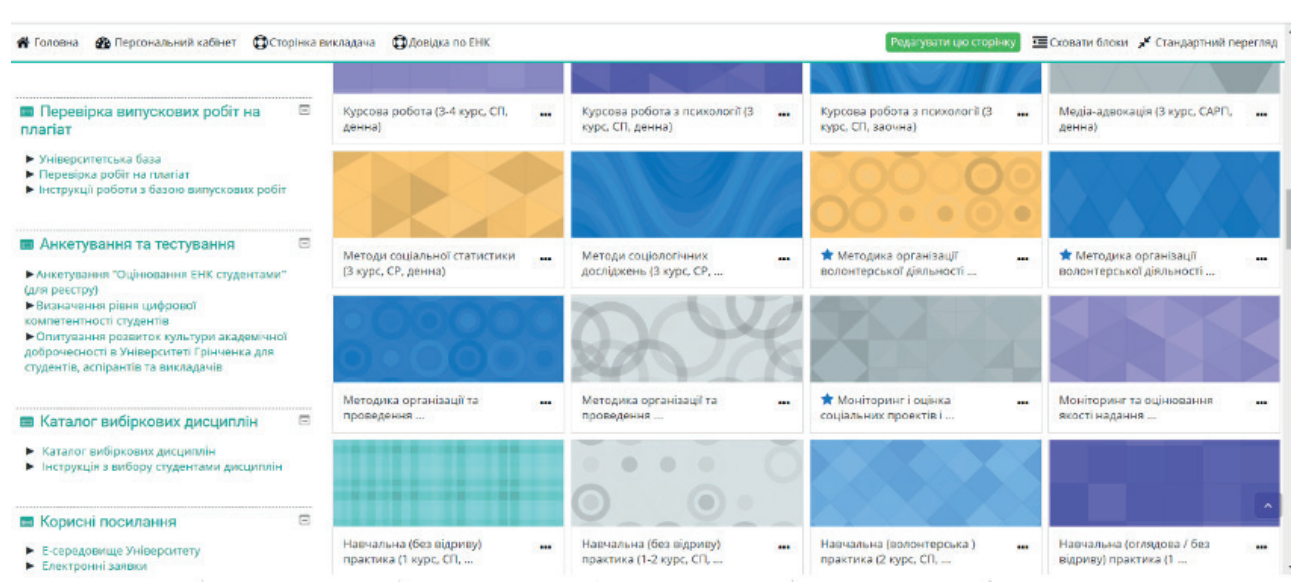

F ig u r e 1. The platform for online learning at Borys Grinchenko Kyiv University

S o u r c e: own work based on the Moodle LMS (site https://elearning.kubg.edu.ua/).

Distance learning includes the following elements: means of providing educational material to the student; means of monitoring student performance; means of consulting the student by the program-teacher; means of interactive cooperation between teacher and student; the ability to quickly add new course information, correction of errors (Morze \& Vember et al., 2019).

There are four types of subjects in the system of distance learning: a student - one who studies; a tutor - one who teaches; an organizer - one who plans educational activities, develops curricula, deals with the distribution of students in groups and the workload of tutors, solves various organizational issues; an administrator - one who ensures the stable functioning of the system, solves technical problems, monitors the statistics of the system.

The organization of an effective distance learning process requires systematic work with the program shell of both the student and the tutor, almost every day throughout the training period.

\section{Training of social work specialists at Borys Grinchenko Kyiv University in the context of the COVID-19 pandemic}

Information and communication technologies are gradually changing the structure of teaching and learning disciplines, and also add new elements and platforms for learning. Computerization of the educational process and the use of distance learning is one of the ways to increase its efficiency. The latest technologies increase the flexibility of learning, ie students can access knowledge regardless of time and geographical barriers. Therefore, information and communication technologies proved to be extremely relevant and important in the context of the COVID-19 pandemic, which minimized offline communication within universities.

Teachers, in particular socionomic specialties, which include social work, faced a difficult task - to provide quality training in a short time with the help of ICT, to form general and special competences of higher education, and also achieve program 
results provided by educational programs. And this was a serious challenge because most disciplines required interaction, group work, "live discussion" of problem situations, special training as a form of work.

In the context of the COVID-19 pandemic, the Department of Social Pedagogy and Social Work of Borys Grinchenko Kyiv University has introduced several ICTs into the educational process, taking into account professional competencies and program results.

So, training of social work specialists at Borys Grinchenko Kyiv University is carried out according to the educational programs of the first (bachelor's) and the second (master's) levels of higher education, based on the Standard of higher education in the specialty 231 "Social Work" (On approval of the Standard..., 2019).

The purpose of the educational programs is to train competent competitive specialists in the field of social work, capable to perform their duties at a high professional level and solving practical problems in the process of professional activity (Table 1).

Table 1. Educational programs in the specialty 231"Social work

\begin{tabular}{|c|c|c|}
\hline $\begin{array}{c}\text { Level of } \\
\text { education }\end{array}$ & $\begin{array}{c}\text { Educational } \\
\text { program }\end{array}$ & The focus of the educational program \\
\hline \multirow{3}{*}{$\begin{array}{l}\text { The first } \\
\text { level of } \\
\text { higher } \\
\text { education } \\
\text { (Bachelor) }\end{array}$} & Social Work & $\begin{array}{l}\text { Formation of knowledge, skills, and practical skills in } \\
\text { the field of social work with different groups of service } \\
\text { recipients, as well as social work management }\end{array}$ \\
\hline & $\begin{array}{l}\text { Social } \\
\text { Pedagogy }\end{array}$ & $\begin{array}{l}\text { Formation of knowledge, skills, and practical skills in the } \\
\text { field of socio-pedagogical activities with children, youth } \\
\text { and families in various institutions of social education. }\end{array}$ \\
\hline & $\begin{array}{l}\text { Social } \\
\text { Advocacy }\end{array}$ & $\begin{array}{l}\text { Training of a manager in the social field capable to model } \\
\text { and implement social work technologies; to establish ef- } \\
\text { fective social communication between different subjects } \\
\text { of social work in the community. }\end{array}$ \\
\hline \multirow[t]{3}{*}{$\begin{array}{l}\text { The second } \\
\text { level of } \\
\text { higher } \\
\text { education } \\
\text { (Master) }\end{array}$} & Social work & $\begin{array}{l}\text { The content of the subject area includes concepts, laws, } \\
\text { principles, ideas that reveal the development of an indi- } \\
\text { vidual, social group, community, society as a whole and } \\
\text { form the professional competence of a specialist. }\end{array}$ \\
\hline & $\begin{array}{l}\text { Social } \\
\text { pedagogy }\end{array}$ & $\begin{array}{l}\text { Formation of knowledge, skills, and practical skills in } \\
\text { the field of socio-pedagogical activities, organization and } \\
\text { conduct of socio-pedagogical research, implementation } \\
\text { of socio-pedagogical technologies }\end{array}$ \\
\hline & $\begin{array}{l}\text { Monitoring } \\
\text { and } \\
\text { evaluation } \\
\text { of social } \\
\text { programs }\end{array}$ & $\begin{array}{l}\text { The content of the subject area includes the content, } \\
\text { forms, and methods of development, management and } \\
\text { evaluation of social programs and projects, monitoring } \\
\text { and evaluation of the quality of social services by various } \\
\text { actors of social work. }\end{array}$ \\
\hline
\end{tabular}

S our c e: own work based on the educational and professional programs in the specialty 231 "Social work" (site https://il.kubg.edu.ua/struktura/kafedry-instytutu/kafedra-sotsialnoi-pedahohiky-ta-sotsialnoi-roboty/osvitni-prohramy.html). 
The most appropriate ICTs to ensure the formation of professional competencies and program results of educational programs in the specialty 231 Social work in a COVID-19 pandemic are specialized information systems, learning management systems (LMS), or so-called software and pedagogical systems. As a rule, such information systems consist of sets of modules that provide full-fledged distance learning. Multimedia technologies, one of the most promising and popular pedagogical information technologies have become the most common in the process of training a social specialist in the context of the COVID-19 pandemic. They allow you to create entire collections of images, texts and data, accompanied by sound, video, animations, and other visual effects (simulation); include an interactive interface, and other controls.

We will present the professional competences of social work specialists and courses through which they are formed on the example of the educational program "Social Advocacy" of the first (bachelor's) level of higher education (Table 2). (Educational and professional program..., 2019; Lekholetova \& Lyakh, 2020, p. 137).

\section{Ta b le 2. Formation of professional competencies of social work specialists according to the educational program "Social Advocacy" of the first (bachelor's) level of higher education}

\begin{tabular}{|c|c|}
\hline $\begin{array}{l}\text { Professional competences of a social } \\
\text { work specialist of the educational } \\
\text { program "Social Advocacy" }\end{array}$ & $\begin{array}{l}\text { Courses that provide the formation } \\
\text { of professional competence }\end{array}$ \\
\hline $\begin{array}{l}\text { Knowledge and understanding of the } \\
\text { essence, significance, and types of } \\
\text { social work and its main areas }\end{array}$ & $\begin{array}{l}\text { Theory and history of social work; Orga- } \\
\text { nization of intersectoral cooperation in the } \\
\text { social field; Technologies of professional } \\
\text { communication in social work. }\end{array}$ \\
\hline $\begin{array}{l}\text { Knowledge and understanding of the } \\
\text { legal and regulatory framework for } \\
\text { social work and social security }\end{array}$ & $\begin{array}{l}\text { Basics of social and legal protection; Tech- } \\
\text { nology for assessing the needs of recipients } \\
\text { of social services; Media advocacy; Practi- } \\
\text { cum on public speaking; Technologies of } \\
\text { professional communication in social work. }\end{array}$ \\
\hline $\begin{array}{l}\text { Ability to identify, socially inspection } \\
\text { and assess the needs of vulnerable } \\
\text { groups of citizens, including those in } \\
\text { difficult life circumstances }\end{array}$ & $\begin{array}{l}\text { Social work with families; Social work with } \\
\text { people with disabilities; Socio-pedagogical } \\
\text { work with children in conflict with the law; } \\
\text { Social prevention of domestic violence and } \\
\text { child abuse; Technology for assessing the } \\
\text { needs of recipients of social services; Orga- } \\
\text { nization of intersectoral cooperation in the } \\
\text { social sphere. }\end{array}$ \\
\hline $\begin{array}{l}\text { Knowledge and understanding of the } \\
\text { organization and functioning of the } \\
\text { system of social protection and social } \\
\text { services }\end{array}$ & $\begin{array}{l}\text { Social work with families; Organization of } \\
\text { intersectoral cooperation in the social sphere; } \\
\text { Technologies of professional communication } \\
\text { in social work. }\end{array}$ \\
\hline
\end{tabular}




\begin{tabular}{ll}
\hline $\begin{array}{l}\text { Ability to apply modern experimental } \\
\text { methods of working with social ob- } \\
\text { jects in field and laboratory conditions }\end{array}$ & $\begin{array}{l}\text { Information and communication technolo- } \\
\text { gies in social work; Methods and organiza- } \\
\text { tion of social research; Methods of street } \\
\text { social work; Drama practices in social work. }\end{array}$ \\
\hline $\begin{array}{l}\text { Ability to develop ways to overcome } \\
\text { social problems and find effective }\end{array}$ & $\begin{array}{l}\text { Practicum on social advocacy; Organiza- } \\
\text { tion of intersectoral cooperation in the social } \\
\text { ways to solve them }\end{array}$ \\
$\begin{array}{ll}\text { Ability to provide assistance and } \\
\text { support to clients, taking into account } \\
\text { their individual needs, age differences, } \\
\text { gender, ethnicity, and other character- }\end{array}$ & $\begin{array}{l}\text { Social gerontology; Methods of street social } \\
\text { work; Drama practices in social work. }\end{array}$ \\
\hline
\end{tabular}

Ability to develop and implement social projects and programs

\begin{abstract}
Basics of technological support of social work; Methods of social design; Technologies of professional communication in social work; Advertising and communication activities of a social worker.
\end{abstract}

Ability to promote the welfare and social protection of individuals, social assistance, and support to those in difficult living conditions

Ability to select and apply various methods of social advocacy, to develop programs of advocacy campaigns

S o u c e: our work is based on the Standard of higher education in the specialty 231 "Social work" and educational-professional program 231.00.04 "Social advocacy" for the first (bachelor's) level of higher education (Standard of higher education..., 2019; Educational and professional program..., 2019).

The main ICT in the process of distance learning, used by teachers of the Department of Social Pedagogy and Social Work in the context of the COVID-19 pandemic, are:

- Electronic lecturers, simulators, textbooks, encyclopedias;

- Creation and use of presentations and educational materials;

- Providing distance learning through Google MEET, ZOOM for practical classes during group work; 
- Recording lectures in the Distance Learning Studios of the Borys Grinchenko Kyiv University and posting them on the YouTube channel of the Distance Learning Centre in limited or public access (optional) for applicants;

- Development of situational role-playing and intellectual games using artificial intelligence (AI). The use of artificial intelligence allows you to solve the difficult problems. For example, a set of software techniques used in computer games to create the illusion of intelligence in the behavior of computer-controlled characters;

- Modeling of processes and phenomena, acting out situations in pairs or groups with online counseling by an external expert;

- Conducting interactive educational teleconferences and workshops;

- Building a system of control and testing of knowledge and skills of students (use of control test programs);

- Watching movies and cartoons with further discussion of situations and highlighted problems, finding the effective solutions;

- Students search for prevention, advocacy and informational videos through the YouTube channel, other video hosting, and social networks;

- Implementation of design and research activities of students and teachers using Google Forms, telephone surveys, applying Viber, WhatsApp, Telegram, other social networks.

The application of distance learning technologies in modern conditions of training the social work specialists provide various possibilities, such as interactive teacherstudent interaction in dialogue mode (option to receive a consultation, the operative decision of problem situations of educational, methodological, and organizational nature); fast delivery of educational materials to the student in electronic form; operational access to the Internet databases; remote testing; passing a virtual laboratory practicum; creation of "virtual groups" for the implementation of group training projects, and other (Morze \& Vember et al., 2019). All of the above provides a basis for achieving learning outcomes in the training of social work specialists during a difficult period for the country. The program results of training specialists for the educational program "Social Advocacy" include:

1. search, analysis, and synthesis of information from various sources to solve professional problems and establish causal links between social events and phenomena;

2. fluency in oral and written communication in state and foreign languages on professional issues;

3. identification, formulation and solution of problems in the field of social work, integration of theoretical knowledge and practical experience;

4. formulation of own reasonable judgments based on the analysis of a social problem;

5. theoretical argumentation of ways to overcome problems and difficult life circumstances, the choice of effective methods for solving them, predicting the consequences;

6. development of long-term and current plans, programs of actions, operative effective decisions in difficult situations; 
7. use of specialized software in solving professional tasks;

8. critical analysis and evaluation of the current social policy of the country, socio-political processes at the national, regional, and local levels;

9. use of relevant scientific research and application of research professional skills in providing social assistance;

10. analysis of socio-psychological processes in small and large groups;

11. application of prevention methods to avoid possible mental development deviations, behavioral disorders, problems of interpersonal relationships, to resolve conflicts, to prevent social risks and difficult life circumstances;

12. determination the content of cooperation with partner organizations in social work to perform the tasks of professional activity;

13. application of social diagnostic methods in the process of assessing the problems, needs, specific features, and resources of clients;

14. application of forms and methods of advocacy campaigns depending on the challenges of social reality;

15. making practical decisions to improve social welfare and to increase social security;

16. application of management methods to organize own professional activities and manage the activities of social workers and volunteers, other staff;

17. establishment and support of relationships with clients based on mutual trust and in accordance with the ethical principles and standards of social work, providing them with psychological support, and empowerment of clients;

18. establishment of cooperation with representatives of various professional groups and communities; using strategies of individual and collective representation of clients' interests;

19. identification of potential risk groups of consumers of social services requiring the advocacy of a social worker in various institutions;

20.identification of ethical dilemmas and contradictions in professional activities and the application of means of supervision to address them;

21. demonstration of tolerant behavior, respect for cultural, religious, ethnic differences, the distinction of stereotypes and prejudices;

22. demonstration of the ability to creatively solve problems and make innovative decisions, to think and apply creative abilities to form innovative ideas;

23. construction of the process and result of social work within the set tasks, application of quantitative and qualitative indicators, adjustment of the work plan following the results of the assessment;

24. development of social advocacy campaigns to establish effective interagency communication.

Students consider distance learning to be convenient and practical (Pavliuk \& Muzychenko et al., 2020). The main benefits of distance learning in the context of the COVID-19 pandemic include: the presentation of the course material, taking into account the training and abilities of students; introduction of the newest pedagogical, psychological, and methodical developments; self-paced learning, training at a convenient time, in a certain place, getting an education without leaving the main work, no time limits for learning the material; breaking the material into separate function- 
ally complete topics, which can be studied as they are mastered and correspond to the abilities of an individual student or a group as a whole; active communication between students of the group and the teacher, which significantly increases the motivation to learn, improves the assimilation of the material; greater opportunities to control the quality of education, providing discussions, chats, self-control, no psychological barriers; and no geographical boundaries for education.

\section{CONCLUSION}

The introduction and implementation of distance learning tools in the education process in the context of the COVID-19 pandemic are expected to improve the quality of professional training of higher education students, in particular, in the formation of professional competences of social workers. Among the expected results are $100 \%$ provision of E-learning system content of the disciplines of the Department of Social Pedagogy and Social Work for students of the first (bachelor's) and second (master's) levels of higher education; development and implementation of video seminars, webinars, video lectures with the application of modern digital technologies, and other. It should be noted that the expected results of distance learning of social work specialists in the context of the COVID-19 pandemic intersect with the expected results of the implementation of the university concept of digitalization.

\section{REFERENCES}

Buinytska, O., Varchenko-Trotsenko, L., Erletska, T., \& Nastas, D. (2020). Modernization of Electronic Learning System of the University to the Needs of the Participants of the Educational Process. Open Educational E-Environment of Modern University, 9, 1-14. https://doi.org/10.28925/2414-0325.2020.9.1.

Canales Inga, W.V., A smat Vega, N.S., Engracio Salinas, J.A., \& Núñez Lira, L.A. (2021). Higher education in times of health crisis 2020. LAPLAGE EM REVISTA, 7(3C), 60-72. https://doi.org/10.24115/s2446-6220202173c1504p.60-72.

Development strategy (program) of Borys Grinchenko Kyiv University for 2018-2022. (2018). KUBG. Retrieved from https://kubg.edu.ua/images/stories/Departaments/documents/ bgku_development_strategy_2018-2022.pdf (accessed 10 June 2021) (in Ukrainian).

Domínguez-Lloria, S., Fernández-Aguayo, S., Marín-Marín, J.-A., \& Alvari ñ a -Villaverde, M. (2021). Effectiveness of a Collaborative Platform for the Mastery of Competencies in the Distance Learning Modality during COVID-19. Sustainability, 13(11), 5854. https://doi.org/10.3390/su13115854.

Educational and professional program 231.00.04 Social advocacy for students of the first (bachelor's) level of higher education (2019). Working group: T.L. Lyakh, S.V. Sapiga, T.P. Spirina. KUBG. Retrieved from https://kubg.edu.ua/images/stories/Departaments/vstupnikam/il/2019/OPP_soc_advokaciia.pdf (accessed 5 June 2021) (in Ukrainian).

García - Peñalvo, F.J., García - Holgado, A., Vá zquez-Ingel mo, A., \& SánchezPri e to, J.C. (2021). Planificación, comunicación y metodologías activas: Evaluación online de la asignatura ingeniería de software durante la crisis del COVID-19. RIED. Re- 
vista Iberoamericana De Educación a Distancia, 24(2), 41. https://doi.org/10.5944/ried. 24.2.27689.

Iva niuk, I. \& Ovcharuk, O. (2020). The response of Ukrainian teachers to COVID-19: Challenges and needs in the use of digital tools for distance learning. Information Technologies and Learning Tools, 77(3), 282-291. https://doi.org/10.33407/itlt.v77i3.3952

Kuzm inska, O., Mazorchuk, M., Morze, N., \& Kobylin, O. (2020). Digital Learning Environment of Ukrainian Universities: The Main Components to Influence the Competence of Students and Teachers. In: V. Er molayev, F. Mallet, V. Ya kov yna, H. Mayr, \& A. Spivakovsky (Eds.). Information and Communication Technologies in Education, Research, and Industrial Applications. ICTERI 2019. Communications in Computer and Information Science (pp. 210-230). Vol. 1175. Springer, Cham. https://doi. org/10.1007/978-3-030-39459-2_10.

Lek holet ova, M. \& Ly a kh, T. (2020). Preparation of future social workers for advocacy. Pedagogical sciences: theory, history, innovative technologies (pp. 139-160). Vol. 2(96). https://doi.org/10.24139/2312-5993/2020.02/135-144 (in Ukrainian).

Morze, N., Buinytska, O. (2019). Digital Competencies of University Teachers. In: E. Smyrnova-Trybulska, P. Ko m mers, N. Morze, J. Malach (Eds.). Universities in the Networked Society. Critical Studies of Education (pp. 19-37). Vol. 10. Springer, Cham. https://doi.org/10.1007/978-3-030-05026-9_2.

Morze, N., Varchenko-Trotsenko, L., Terletska, T., \&Smyrnova-Trybulska, E. (2021). Implementation of adaptive learning at higher education institutions by means of Moodle LMS. Journal of Physics: Conference Series. Vol. 1840. IOP Publishing Ltd. https://doi.org/10.1088/1742-6596/1840/1/012062.

Morze, N., Ve mb er, V., \& Var chenko-Trot s e n k o, L. (2019). How to create an effective flipped learning sequence in higher education. E-learning and STEM Education In: E. S m y r n ov a - Tr y bu lska. "E-learning", 11, Katowice-Cieszyn: STUDIO NOA for University of Silesia (pp. 139-160). https://doi.org/10.34916/el.2019.11.10.

Noskova, T., Pavlova, T., \& Yakovleva, O. (2019). Professional Training: Challenges in the Digital Economy Context. In: E. Smyrnova-Trybulska, P. Kommers, N. Morze, J. Mala ch (Eds.). Universities in the Networked Society. Critical Studies of Education (pp. 39-48). Vol. 10. Springer, Cham. https://doi.org/10.1007/978-3-030-05026 $-9+3$.

On approval of the Standard of higher education in the specialty 231 "Social work" for the first (Bachelor's) level of higher education (2019). Retrieved from https://mon.gov.ua/ storage/app/media/vishcha-osvita/zatverdzeni\%20standarty/2019/04/25/231-sotsialnarobota-bakalavr.pdf (accessed 5 June 2021) (in Ukrainian).

On prevention of the spread of COVID-19 acute respiratory disease caused by the SARSCoV-2 coronavirus in Ukraine (2020). Resolution of the Cabinet of Ministers of Ukraine dated March 11, 2020 № 211]. Retrieved from https://zakon.rada.gov.ua/laws/show/3922020-п?lang=uk\#Text (accessed 1 June 2021) (in Ukrainian).

Pavliuk, R.O. \& Liakh, T.L. (2019). Approaches to the Development of the ICT Competence Standard in the System of Research-Based Training for the Future Specialist of Social Sphere in Ukraine. In: E. S m y r nova-Trybulska, P. Ko m mers, N. Morze, J. Ma la ch (Eds.). Universities in the Networked Society. Critical Studies of Education (pp. 201-222). Vol. 10. Springer, Cham. https://doi.org/10.1007/978-3-030-05026-9_12. 
Pavliuk, R., Liakh, T., Bezpalko, O., \& Klishevych, N. (2017). Research-Based Training: Methodological Characteristics and Results of the Analysis of Educational Programs. Social Sciences, 6(4), 152. https://doi.org/10.3390/socsci6040152.

Pavliuk, R., Muzychenko, I., Kohut, I., \& Sulaieva, N. (2020). The quality of providing educational services in the higher education system in Ukraine: Students' opinion. AGATHOS, 11, 2(21), 207-219. Retrieved from https://elibrary.kubg.edu.ua/id/ eprint/32522/1/29.Pavliuk.pdf ISSN 2069-1025 (accessed 15 June 2021).

Regueiro, B., Rodríg ue z- Fer nán de z, J.E., Cre s po, J., \& P in o - Ju ste, M.R. (2021, April). Design and Validation of a Questionnaire for University Students' Generic Competencies (COMGAU). In Frontiers in Education (p. 124). Vol. 6. Frontiers. https://doi. org/10.3389/feduc.2021.606216.

Regulations on the organization of the education process at the Borys Grinchenko Kyiv University (2017). Borys Grinchenko Kyiv University. Retrieved from https://fzfvs.kubg. edu.ua/images/stories/Departaments/ilid/ogolosenia/6kyki.pdf (accessed 10 June 2021) (in Ukrainian).

Regulations on the procedure for exercising the academic mobility right by the participants of the education process of Borys Grinchenko Kyiv University (2018). KUBG. Retrieved from https://kubg.edu.ua/images/stories/Departaments/vdd/documenty/rozdil12/polozh_ 839_22.12.2018.pdf (accessed 5 June 2021) (in Ukrainian).

The concept of digitalization of Borys Grinchenko Kyiv University for 2020-2022 (2020). Borys Grinchenko Kyiv University. Retrieved from https://kubg.edu.ua/images/stories/ Departaments/vdd/documenty/rozdil_7/concept_digital-20.pdf (accessed 15 June 2021) (in Ukrainian). 